\title{
Development and validation of primary human myometrial cell culture models to study pregnancy and labour
}

\author{
Andrea A Mosher ${ }^{1}$, Kelly J Rainey ${ }^{1}$, Seunghwa S Bolstad', Stephen J Lye ${ }^{2}$, Bryan F Mitchell ${ }^{3}$, David M Olson ${ }^{3}$,
} Stephen L Wood ${ }^{4}$, Donna M Slater ${ }^{1,4^{*}}$

\begin{abstract}
Background: The development of the in vitro cell culture model has greatly facilitated the ability to study gene expression and regulation within human tissues. Within the human uterus, the upper (fundal) segment and the lower segment may provide distinct functions throughout pregnancy and during labour. We have established primary cultured human myometrial cells, isolated from both upper and lower segment regions of the pregnant human uterus, and validated them for the purpose of studying human pregnancy and labour. The specific objectives of this study were to monitor the viability and characterize the expression profile using selected cellular, contractile and pregnancy associated markers in the primary cultured human myometrial cells. Labour has been described as an inflammatory process; therefore, the ability of these cells to respond to an inflammatory stimulus was also investigated.
\end{abstract}

Methods: Myometrial cells isolated from paired upper segment (US) and lower segment (LS) biopsies, obtained from women undergoing Caesarean section deliveries at term prior to the onset of labour, were used to identify expression of; $\alpha$ smooth muscle actin, calponin, caldesmon, connexin 43, cyclo-oxygenase-2 (COX-2), oxytocin receptor, tropomyosin and vimentin, by RT-PCR and/or immunocytochemistry. Interleukin (IL)-1 $\beta$ was used to treat cells, subsequently expression of COX-2 mRNA and release of interleukin-8 (CXCL8), were measured. ANOVA followed by Bonferroni's multiple comparisons test was performed.

Results: We demonstrate that US and LS human myometrial cells stably express all markers examined to at least passage ten (p10). Connexin 43, COX-2 and vimentin mRNA expression were significantly higher in LS cells compared to US cells. Both cell populations respond to IL-1 $\beta$, demonstrated by a robust release of CXCL8 and increased expression of COX-2 mRNA from passage one (p1) through to p10.

Conclusions: Isolated primary myometrial cells maintain expression of smooth muscle and pregnancy-associated markers and retain their ability to respond to an inflammatory stimulus. These distinct myometrial cell models will provide a useful tool to investigate mechanisms underlying the process of human labour and the concept of functional regionalization of the pregnant uterus.

\section{Background}

Efforts to understand mechanisms regulating the balance between uterine quiescence and contractions are a main focus of research in obstetrics, especially preterm labour. Of particular interest are the myometrial smooth muscle

\footnotetext{
* Correspondence: dmslater@ucalgary.ca

'Department of Physiology \& Pharmacology, University of Calgary, Calgary, Alberta, Canada

Full list of author information is available at the end of the article
}

cells as these constitute the contractile machinery of the uterus and may offer a therapeutic target for the prevention of premature myometrial contractions. Cell culture provides a valuable in vitro tool to study many human tissues and organs with the potential to gain insight into various physiological and pathological processes. However, there are concerns about the lifespan of cultured primary cells and their ability to continue to be representative of the tissue of origin. Therefore, we have established
C Biomed Central

C 2013 Mosher et al; licensee BioMed Central Ltd. This is an Open Access article distributed under the terms of the Creative Commons Attribution License (http://creativecommons.org/licenses/by/2.0), which permits unrestricted use, distribution, and reproduction in any medium, provided the original work is properly cited. 
primary cultured human myometrial cells isolated from myometrial tissue biopsies obtained during elective Caesarean section deliveries at term, prior to the onset of labour, and validated their usefulness for studying pregnancy and labour.

It has been hypothesized that the upper and lower regions of the human uterus are functionally distinct [1]. During labour, the upper segment has a more contractile phenotype, contracting to push down and initiate delivery of the baby, whilst the lower segment, maintains a more relaxed phenotype, to facilitate delivery of the baby through the lower segment of the uterus and cervix. A number of genes, thought to be involved in the onset of labour, have been shown to be differentially expressed in upper and lower segment myometrial tissues [2-7]. These observations support the notion that upper and lower segments of the pregnant human uterus may be functionally distinct.

The objective of the current study was to establish primary cultures of human myometrial cells isolated from paired upper and lower segment myometrial biopsies for ten passages and evaluate and compare the expression of smooth muscle markers, fibroblast markers, contractile proteins or labour associated proteins over time. For the purpose of this study, smooth muscle markers were defined as; $\alpha$ smooth muscle actin, calponin, caldesmon, and tropomyosin, since $\alpha$ smooth muscle actin is part of the contractile machinery of smooth muscle cells and calponin, caldesmon, and tropomyosin are proteins that modulate muscle cell contractility through their ability to bind to $\alpha$ smooth muscle actin [8-10]. Fibroblast markers used were vimentin, a filament protein that is typically used to identify fibroblasts $[11,12]$ and a fibroblast surface protein called IB10 (http://Abcam.com). The gap junction protein, connexin 43 and the oxytocin receptor are labour associated genes known to be up-regulated at the time of labour onset in human myometrium [3,5,13,14].

In addition, labour is commonly considered an inflammatory process and up-regulation of inflammatory genes including interleukin-1 $\beta$ (IL-1 $\beta$ ), cyclo-oxygenase-2 $(C O X-2)$ and interleukin-8 (CXCL8) is observed $[15-17,5]$. We therefore tested the ability of the upper segment myometrial cells to respond to an inflammatory stimulus compared to lower segment cells. For this study, interleukin-1 $\beta$ (IL-1 $\beta$ ) was used as the inflammatory stimulus, and cyclo-oxygenase-2 (COX-2) mRNA expression and interleukin-8 (CXCL8) release were the outcomes measured.

\section{Methods}

\section{Sample collection}

Institutional ethical committee approval was obtained (Conjoint Health Research Ethics Board, Office of Medical Bioethics at the University of Calgary) for the collection of myometrial biopsies to study the mechanisms of human labour. Women undergoing delivery by elective caesarean section at term were recruited, fully informed and consented to the study. In the current study, none of the women had any known underlying diseases, all were Caucasian with ages ranging from 25-41. Indications for caesarean delivery included breech presentation or previous caesarean delivery. Gestational age ranged from 38 weeks +4 days to 39 weeks +0 days and no clinical signs of labour were observed. Paired biopsies were collected from the lower and upper regions of the uterus following delivery of the infant. The lower segment biopsy was taken from the exposed myometrium on the upper aspect of the lower segment incision. The upper segment biopsies were all taken from the side opposite the placenta on the anterior or posterior aspect of the upper segment. Palpation and visualization of the uterus determined where the upper segment begins and samples were taken from approximately half way between the upper edge of the lower segment incision and the tip of the fundus. For the upper segment biopsy, the decidual layer was first dissected away and a small piece of myometrium grasped with fine forceps and dissected with Iris scissors. All samples were placed immediately into sterile cold Hank's Balanced Salt Solution (HBSS) (Life Technologies, Burlington, ON, Canada), containing antibiotic-antimycotics (1x Penicillin-Streptomyocin-Amphotericin B) (Gibco, Life Tecnologies, Inc), and transported to the laboratory for myometrial cell isolation within 30 minutes of delivery.

\section{Isolation and culture of primary human myometrial cells}

Myometrial cells were isolated, separately but in parallel, from the paired, upper segment (US) and lower segment (LS) myometrial biopsies. Myometrial cells were isolated from methods adapted from Phaneuf et al., [18] and Tribe et al., [19]. Each biopsy was dissected into $1 \mathrm{~mm}^{3}$ pieces, washed in HBSS to remove excess blood, placed in Smooth Muscle cell medium containing collagenase XI $(1 \mathrm{mg} / \mathrm{ml})$, collagenase IA $(1 \mathrm{mg} / \mathrm{ml})$ and fatty acid free bovine serum albumin (0.5\%) (Sigma-Aldrich, Oakville, $\mathrm{ON}$, Canada), and digested for 60 minutes at $37^{\circ} \mathrm{C}$. Myometrial cells were then dispersed by passing the digestion solution repeatedly through a fine sterile pipette, further digestion was stopped by the addition of $5 \%$ fetal bovine serum (FBS) (Life Technologies) contained in Smooth Muscle Medium (PromoCell, Heidelberg, Germany). Cells were passed through a $70 \mu \mathrm{m}$ sieve, centrifuged for $5 \mathrm{~min}$ utes at $400 \mathrm{~g}$, and re-suspended in Smooth Muscle Medium containing 5\% FBS and $1 \mathrm{x}$ antibiotic-antimycotic. Isolated cells were assessed for viability by the Trypan Blue exclusion method (Life Technologies Inc.) and counted using the Countess Automated Cell Counter (Life Technologies Inc.). Cells were plated into $25 \mathrm{~cm}^{2}$ culture flasks (Corning Inc., Lowell, MA, USA), incubated at $37^{\circ} \mathrm{C}$ 
in a humidified atmosphere of $95 \%$ air $/ 5 \% \mathrm{CO}_{2}$ and the culture medium replaced every 2 days. The initial stage of cell growth was termed passage $0(\mathrm{p} 0)$. At approximately 10-14 days following initial isolation when myometrial cell growth reached $80-90 \%$ confluence (\% coverage of cells in the culture flask) the cells were sub-cultured (passaged) and plated at a density of $4.0 \times 10^{4}$ cells $/ \mathrm{ml}$ into a larger $150 \mathrm{~cm}^{2}$ culture flask and termed, passage $1(\mathrm{p} 1)$.

For the current series of experiments LS and US myometrial cells were sub-cultured from passage 1 through to passage 10 at a density of $4.0 \times 10^{4}$ cells $/ \mathrm{ml}$ into a $150 \mathrm{~cm}^{2}$ culture flask and 12-well plates (Corning Inc.) to assess changes in; (i) cell viability and population doubling, (ii) expression of contractile markers (mRNA and protein) and, (iii) the response to treatment with the inflammatory

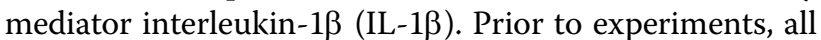
cells were serum deprived overnight (Smooth Muscle Medium 0.5\% FBS), then incubated for 6 hours with either $1 \mathrm{ng} / \mathrm{ml}$ IL-1 $\beta$ (Research \& Development Systems, Minneapolis, MN, USA) or non-treated (NS). Culture supernatants were collected and stored at $-20^{\circ} \mathrm{C}$ while cell culture plates were stored at $-80^{\circ} \mathrm{C}$ prior to RNA isolation. $R N A$ isolation, conventional RT-PCR and real-time RT-PCR Total RNA was isolated from human myometrial cells using the Qiagen RNeasy Mini Kit (Qiagen Inc., Toronto,
ON, Canada) and $500 \mathrm{ng}$ used for reverse transcription and synthesis of complementary DNA (cDNA) with qScript cDNA SuperMix (Quanta BioSciences Inc., Gaithersburg, MD, USA). Negative reverse transcription reactions were performed as a control, in which the reverse transcriptase enzyme was absent. Conventional RT-PCR was performed on an Eppendorf EPS Mastercycler (Eppendorf Canada, Mississauga, ON, Canada) with an initial denaturing step of 2 minutes at $94^{\circ} \mathrm{C}$, followed by $32-36$ cycles of denaturing at $94^{\circ} \mathrm{C}$, annealing at $58^{\circ} \mathrm{C}$ $-60^{\circ} \mathrm{C}$, and elongation at $72^{\circ} \mathrm{C}$, with a final elongation step at $72^{\circ} \mathrm{C}$ for 5 minutes. RT-PCR products were first analyzed by agarose gel electrophoresis to confirm the RT-PCR amplification product was the correct size. Subsequently, RT-PCR products were purified using a Qiagen MinElute PCR Purification Kit (Qiagen Inc.), and verified by sequencing (DNA Sequencing Services, University of Calgary). Real-time RT-PCR was performed on the Applied Biosystems 7900HT machine in 96-well Fast Optical MicroAmp Plates (Applied Biosystems, Life Technologies) with SYBR Green qPCR SuperMix (Quanta BioSciences Inc.). All protocols were performed according to manufacturer's instructions. See Table 1 for PCR primer sequences. Melt curve analysis was performed to verify that non-specific amplification products

Table 1 Primer sequences

\begin{tabular}{|c|c|c|c|}
\hline Name & Primer Sequences $\left(5^{\prime}-3^{\prime}\right)$ & $\begin{array}{l}\text { Product Size Conventional } \\
\text { Or real-time }\end{array}$ & $\begin{array}{l}\text { Target Gene(GenBank } \\
\text { Accession) }\end{array}$ \\
\hline$\beta 2$-microglobulin & $\begin{array}{l}\text { F: } \\
\text { CTTATGCACGCTTAACTATCTTAACAA } \\
\text { R: TAGGAGGGCTGGCAACTTAG }\end{array}$ & $\begin{array}{l}\text { 127bp } \\
\text { Real-time }\end{array}$ & $\begin{array}{l}\text { B2M } \\
\text { NM_004048 }\end{array}$ \\
\hline Calponin & $\begin{array}{l}\text { F: GATGGCATCATTCTTTGCGA } \\
\text { R: TTGTAGTAGTTGTGTGCGTG } \\
\text { F: CTGAGAGAGTGGATCGAGGG } \\
\text { R: TGATCTCTTCACGGAGCCT }\end{array}$ & $\begin{array}{l}\text { 701bp } \\
\text { Conventional } \\
\text { 127bp } \\
\text { Real-time }\end{array}$ & $\begin{array}{l}\text { CNN1 } \\
\text { NM_001299 }\end{array}$ \\
\hline Connexin 43 & $\begin{array}{l}\text { F: GTGCCTGAACTTGCCTITTC } \\
\text { R: GATGATGTAGGTTCGCAGCA } \\
\text { F: GGAGTTCAATCACTTGGCGT } \\
\text { R: ACACCTTCCCTCCAGCAGTT }\end{array}$ & $\begin{array}{l}\text { 522bp } \\
\text { Conventional } \\
\text { 134bp Real-time }\end{array}$ & $\begin{array}{l}\text { GJA1 } \\
\text { NM_000165 }\end{array}$ \\
\hline $\begin{array}{l}\text { Cyclo-oxygenase-type } 2 \text { also known as } \\
\text { Prostaglandin GH synthase-2 }\end{array}$ & $\begin{array}{l}\text { F: AGATCATCTCTGCCTGAGTATCTT } \\
\text { R: } \\
\text { TTCAAATGAGATTGTGGAAAAATTGCT } \\
\text { F: GCTGGGCCATGGGGTGGACT } \\
\text { R: CCTGCCCCACAGCAAACCGT }\end{array}$ & $\begin{array}{l}\text { 305bp } \\
\text { Conventional } \\
\text { 200bp } \\
\text { Real-time }\end{array}$ & $\begin{array}{l}\text { COX-2 or PTGS-2 } \\
\text { NM_000963 }\end{array}$ \\
\hline Glyceraldehyde-phosphatedehydroegnase & $\begin{array}{l}\text { F: CCACCCATGGCAAATTCCATGGCA } \\
\text { R: TCTAGACGGCAGGTCAGGTCCACC }\end{array}$ & $\begin{array}{l}\text { 598bp } \\
\text { Conventional }\end{array}$ & $\begin{array}{l}\text { GAPDH } \\
\text { NM_002046 }\end{array}$ \\
\hline Vimentin & $\begin{array}{l}\text { F: TCAGAGAGAGGAAGCCGAAA } \\
\text { R: GTGAGGGACTGCACCTGTCT } \\
\text { F: GGCTCAGATTCAGGAACAGCATG } \\
\text { R: CCTGTCTCCGGTACTCAGTGGAC }\end{array}$ & $\begin{array}{l}\text { 380bp } \\
\text { Conventional } \\
\text { 230bp } \\
\text { Real-time }\end{array}$ & $\begin{array}{l}\text { VIM } \\
\text { NM_003380 }\end{array}$ \\
\hline
\end{tabular}

Sequence of primers used for conventional and real-time RT-PCR analysis. 
were not present. Gene expression was normalized to the reference gene $\beta 2$-microglobulin $(\mathrm{B} 2 \mathrm{M})$ and results calculated using the $\Delta \Delta C_{\mathrm{T}}$ method [20].

\section{ELISA}

The chemokine, CXCL8 was quantified by a sandwich enzyme-linked immunosorbent assay (ELISA) (Human DuoSet $^{\mathbb{R}}$, Research \& Development Systems, Minneapolis, MN, USA) according to manufacturer's instructions. Optical density was measured at $450 \mathrm{~nm}$ using a DTX880 Multimode Detector (Beckman Coulter Canada Inc., Mississauga, ON, Canada).

\section{Immunocytochemistry}

Cells were also seeded onto 8-chamber glass culture slides (ThermoFisher Scientific, Ottawa, ON, Canada) at passage 1 , passage 5 and passage 10 and grown to $80-90 \%$ confluence. Cells were rinsed in phosphate-buffered saline (PBS), fixed in $4 \%$ paraformaldehyde for 20 minutes at $37^{\circ} \mathrm{C}$ and permeabilized in $0.1 \%$ Triton-X in PBS for 15 minutes at room temperature. Myometrial cells were treated using a Dako kit (Dako Canada Inc., Burlington, ON, Canada) according to the manufacturer's instructions. Briefly, cells were incubated for 10 minutes in $1.5 \%$ blocking serum in PBS at room temperature prior to incubation with primary antibody (Table 2). Cells were washed in PBS and incubated with biotinylated goat anti-rabbit and anti-mouse secondary antibody followed by peroxidase substrate. Finally, cells were counterstained in Harris' haematoxylin and mounted with Dako Faramount Aqueous Mounting Medium. Images were obtained using a Zeiss Axio Scope connected to an Axiocam ICc 3 camera and AxioVision 4.8.2 software (Carl Zeiss Canada Ltd., BC, Canada).

\section{Statistical analysis}

All experiments were performed using paired upper and lower segment cells isolated from $n=4$ patients. All

Table 2 Antibody Information

\begin{tabular}{llll}
\hline Protein & $\begin{array}{l}\text { Antibody } \\
\text { information }\end{array}$ & Clonality & $\begin{array}{l}\text { Dilution for } \\
\text { ICC }\end{array}$ \\
\hline $\begin{array}{l}\text { a smooth muscle } \\
\text { actin }\end{array}$ & $\begin{array}{l}\text { sc-58669 (Santa } \\
\text { Cruz) }\end{array}$ & $\begin{array}{l}\text { Mouse } \\
\text { monoclonal }\end{array}$ & 1:1000 \\
\hline Caldesmon & ab32330 (Abcam) & $\begin{array}{l}\text { Rabbit } \\
\text { monoclonal }\end{array}$ & $1: 500$ \\
\hline Calponin & ab46794 (Abcam) & $\begin{array}{l}\text { Rabbit } \\
\text { monoclonal }\end{array}$ & $1: 500$ \\
\hline Oxytocin Receptor & $\begin{array}{l}\text { sc-33209(Santa } \\
\text { Cruz) }\end{array}$ & $\begin{array}{l}\text { Rabbit } \\
\text { polyclonal }\end{array}$ & $1: 200$ \\
\hline Tropomyosin & sc-73225 (Santa & $\begin{array}{l}\text { Mouse } \\
\text { monoclonal }\end{array}$ & $1: 50$ \\
\hline Vimentin & sc-66001 (Santa & $\begin{array}{l}\text { Mouse } \\
\text { monoclonal }\end{array}$ & $1: 1000$ \\
\hline 1B10 & Ab1133) & (Abcam) & $\begin{array}{l}\text { Mouse } \\
\text { monoclonal }\end{array}$ \\
\hline
\end{tabular}

statistical analysis was performed with GraphPad PRISM Software (GraphPad Software Inc., San Diego, CA, USA). Graphical data are presented as the mean \pm SEM. For comparison between two groups, Student's $t$ test were used and for multiple comparisons a one-way analysis of variance (ANOVA) followed by post-hoc test of Bonferroni multiple comparisons. $P<0.05$ was considered statistically significant.

\section{Results}

Through the ten passages cell viability ranged from 78.0 - $93.75 \%$ and $79.5-92.5 \%$ in the US and LS cells respectively. There were no significant differences in cell viability through passage ( $\mathrm{p} 1$ to $\mathrm{p} 10$ ) or when comparing cells isolated from the US versus the LS uterus as shown in Figure 1.

\section{Upper and lower segment human myometrial cells express smooth muscle and fibroblast markers}

Total RNA was isolated from treated and non-treated upper and lower segment human myometrial cells (p1 to p10). Conventional RT-PCR was used to identify the presence of calponin (a smooth muscle marker; gene name CNN1), vimentin (a fibroblast marker; gene name $V I M$ ), and connexin-43 (a gap junction protein; gene name GJA1). GAPDH and B2M were used as reference housekeeping genes for conventional and real-time RTPCR respectively. All four genes were positively identified in both upper and lower segment cells. CNN1, VIM, and GJA1 mRNA expression were not affected by IL-1 $\beta$ treatment (Figure 2A). Qualitative data for $\mathrm{p} 1$ to $\mathrm{p} 4$ is shown in a representative agarose gel figure. The same trend was also observed for p5 to p10 (data not shown). Real-time RT-PCR was then used to quantify mRNA expression comparing upper and lower segment myometrial cells and to determine any changes through passage 1 to 10 . Significantly higher expression of VIM $(P=0.032)$ and GJA1 $(P<0.0001)$ but not $C N N 1(P=0.06)$ was observed in lower segment cells (Figure 2B). Expression of VIM, CNN1 (Figure 3A and B) or GJA1 (data not shown) mRNA were not significantly different through $\mathrm{p} 1$ to $\mathrm{p} 10$.

\section{Upper and lower segment human myometrial cells differentially express COX-2 and respond to an inflammatory stimulus for at least ten passages}

To investigate the upper and lower segment human myometrial cells and the response of the cells to IL- $1 \beta$, expression of cyclo-oxygenase (an inflammatory gene known to be increased during pregnancy and labour; gene name COX-2) mRNA was quantified by real-time RT-PCR and CXCL8 output was measured by ELISA. These outputs were chosen because both COX-2 and CXCL8 are demonstrated to increase in human myometrium with labour $[2,16]$. Expression of COX-2 was first examined comparing 

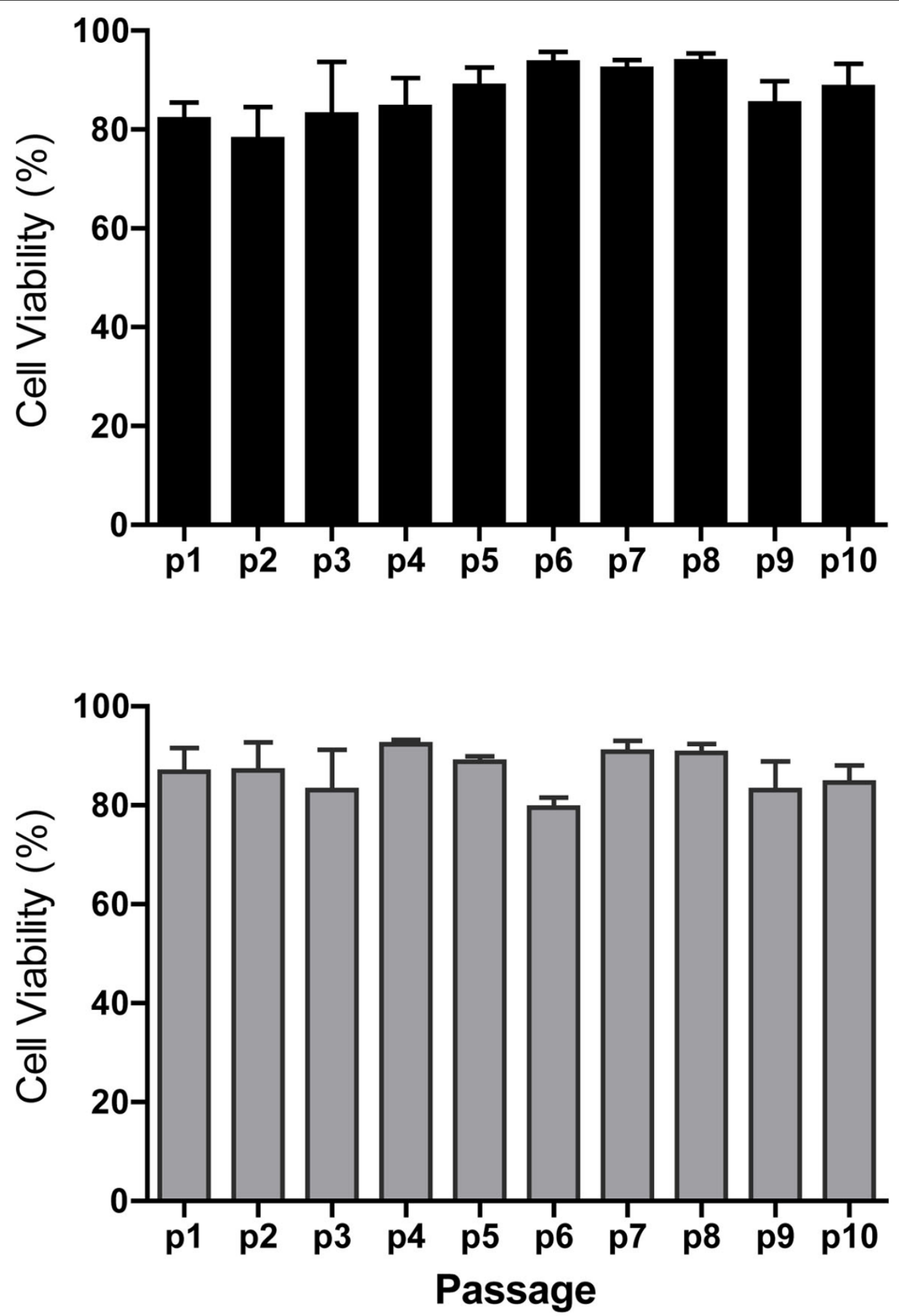

Figure 1 Cell viability from $\mathbf{p} 1$ to $\mathbf{p} 10$ Viability (\% live cells) of cultured upper segment (black bars) and lower segment (grey bars) myometrial cells at passage ( $p 1$ through $p 10)$. Values represent mean +/- SEM.

upper segment versus lower segment cells, In non-treated cells expression of $\mathrm{COX}-2$ was significantly higher in lower segment cells compared to upper segment cells $(P<$ 0.0001) (Figure 4A). Treatment with IL-1 $\beta$ significantly increased COX-2 expression in upper segment cells (Figure 4B) and lower segment cells (Figure 4C). Figure 4D demonstrates the relative expression of COX-2 as a direct comparison in upper, lower, non treated and IL-1 $\beta$ 

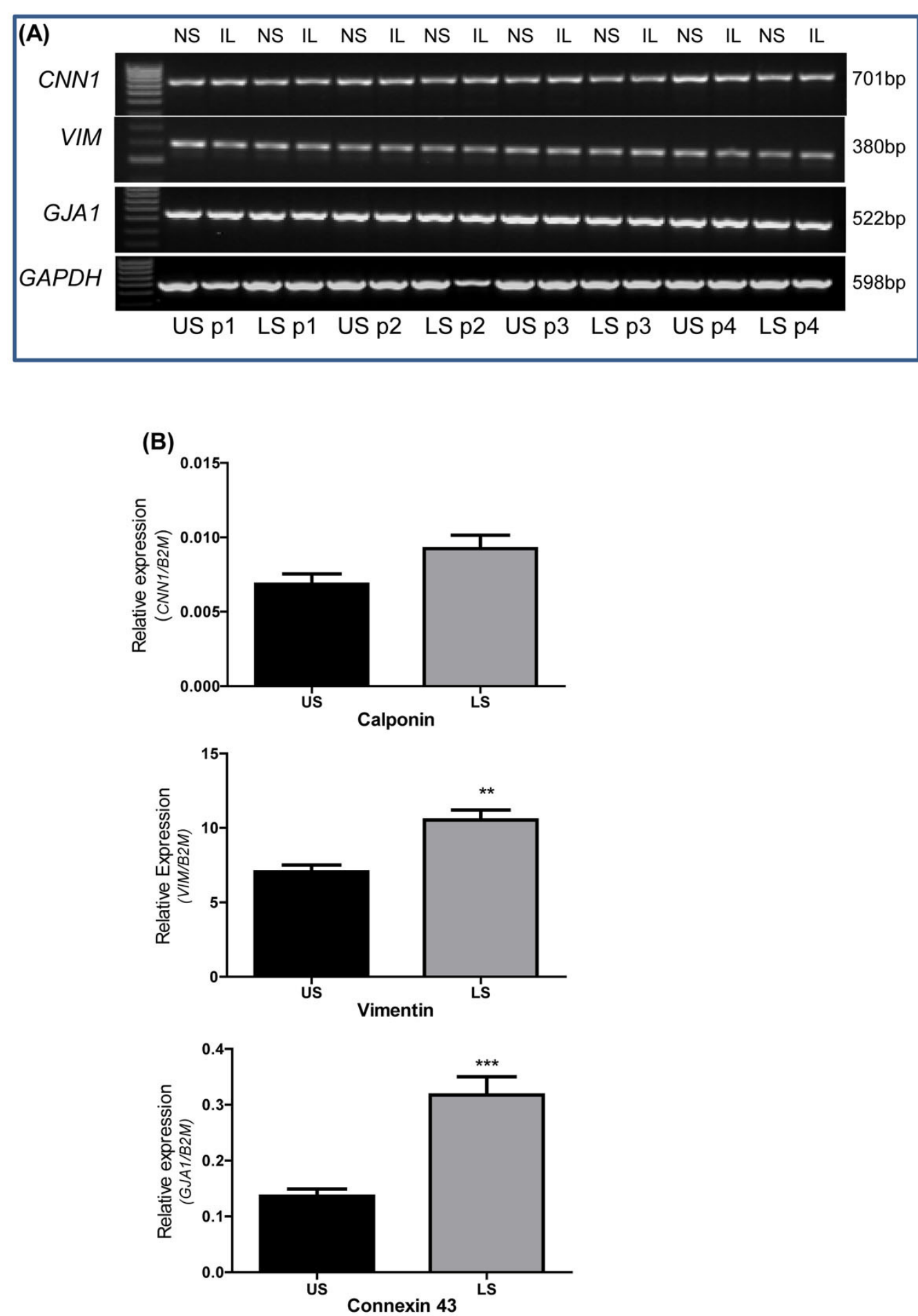

Figure 2 Expression of calponin, vimentin and connexin-43 mRNA in upper and lower segment myometrial cells (A) Representative agarose gel demonstrating expression of calponin (CNN1), vimentin (VIM), connexin 43 (GJA1) and GAPDH mRNA expression in upper and lower

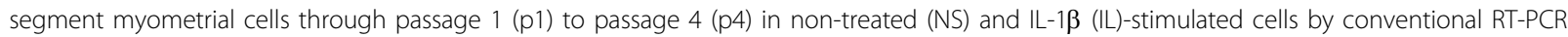
analysis. (B) Real-time RT-PCR analysis identified significantly higher expression of VIM and GJA1 in LS myometrial cells (grey bars) compared to US cells (black bars). Data are presented as the mean \pm SEM of all LS and US cells from $p 1$ through $p 10$ and analyzed by student $t$ test. (** $\left.P=0.003,{ }^{* * *} P<0.0001\right)$. 

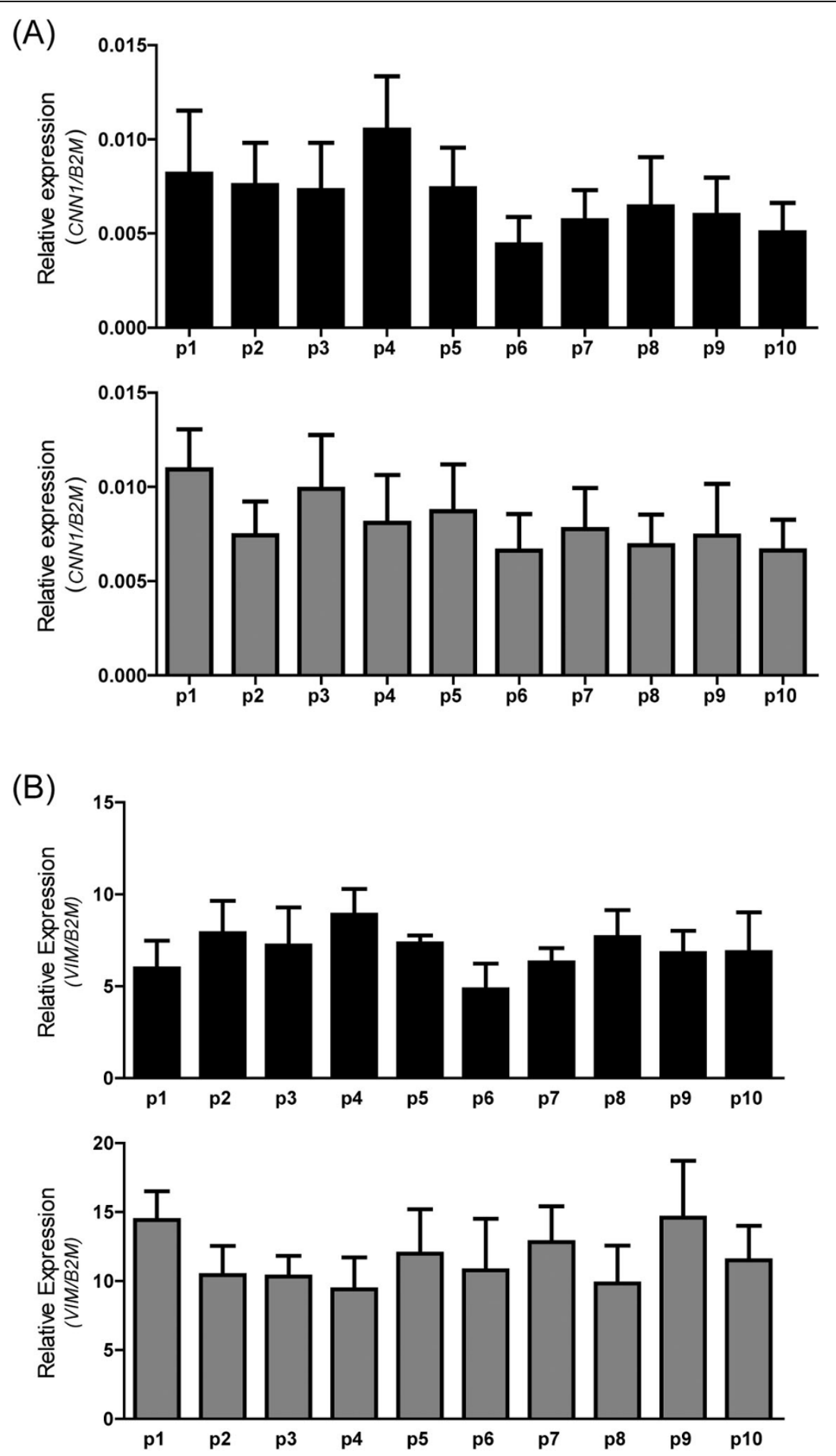

Figure 3 Effect of passage ( $\mathbf{p} 1$ through p10) on mRNA expression Relative expression of (A) calponin (CNN1), and (B) vimentin (VIM) normalized to the reference gene $\beta 2$-microglobulin (B2M). Data represent the mean \pm SEM from US (black) and LS (grey) non-treated cells.

treated cells. IL-1 $\beta$ treatment results in increased expression of COX-2 in both upper and lower segment cells but the increase is much higher in the lower segment cells (Figure 4D).
Comparing passage number, treatment with IL-1 $\beta$ resulted in a robust increase in $C O X-2$ mRNA expression compared to the non-treated in both upper (ANOVA $P=0.0007$ ) and lower (ANOVA $P<0.0001$ ) segment cells 


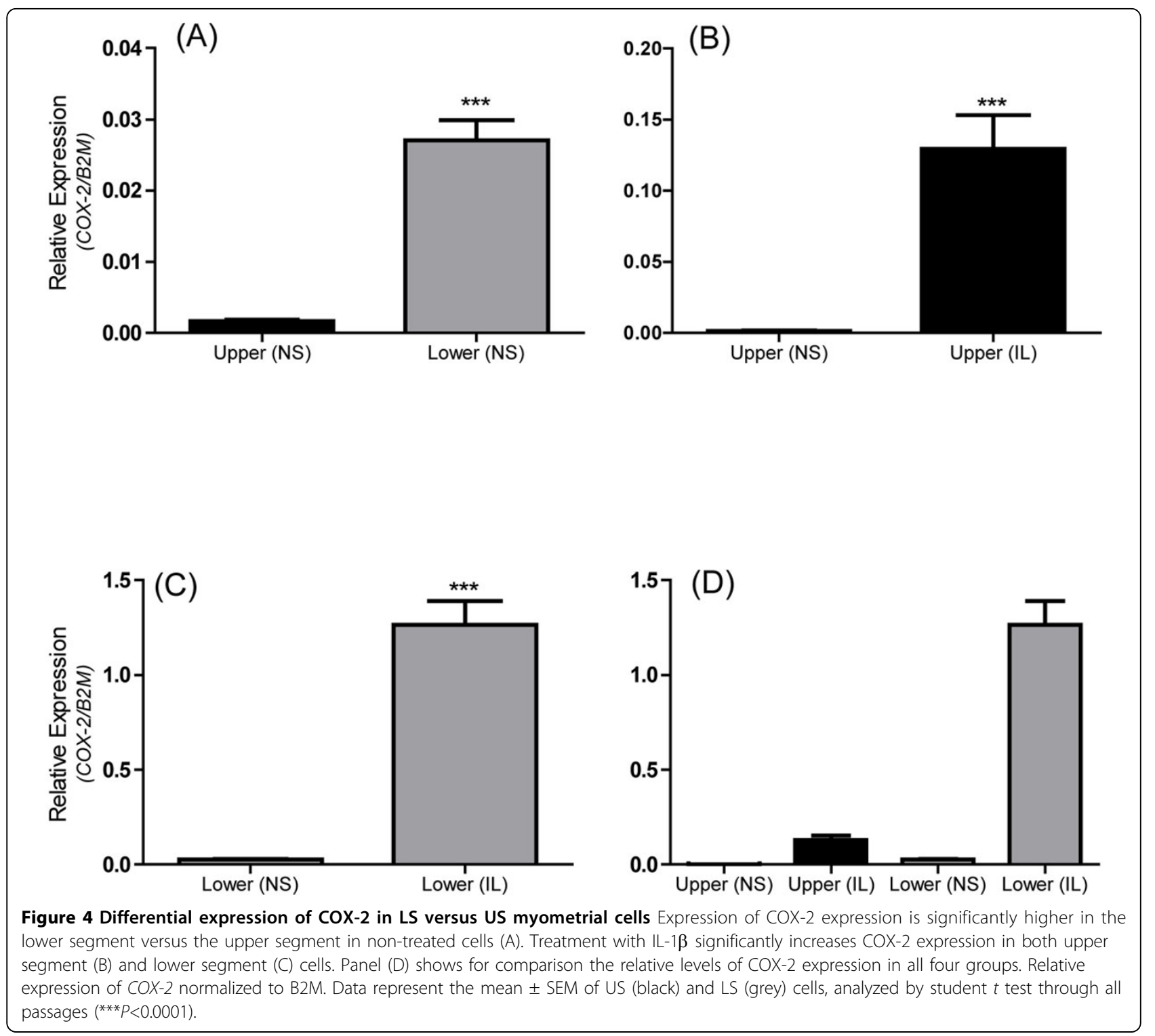

(Figure 5). Treatment with IL-1 $\beta$ also resulted in a robust release CXCL8 (20 000-50 $000 \mathrm{pg} / \mathrm{ml}$ ) in upper (ANOVA $P<0.0001$ ) and lower (ANOVA $P=0.0013$ ) segment cells from 1 through p10 (Figure 6). There were no changes in the response to Il-1 $\beta$ from $\mathrm{p} 1$ through $\mathrm{p} 10$. Therefore, both upper and lower segment human myometrial cells retain their ability to respond to an inflammatory stimulus as demonstrated by increased expression of the inducible $C O X-2$ gene and increased release of the pro-inflammatory chemokine CXCL8.

Upper and lower segment human myometrial cells stain positively for smooth muscle markers, fibroblast protein markers and contractile proteins

Human myometrial cells were seeded on 8-chamber culture slides at passage 2, passage 5 and passage 10 and treated with antibodies to identify protein expression of smooth muscle markers, fibroblasts markers, and the oxytocin receptor (a contractile protein expressed in the pregnant uterus). Upper and lower segment human myometrial cells stained positively for $\alpha$ smooth muscle actin, caldesmon, calponin, tropomyosin, the oxytocin receptor, vimentin and 1B10 at p2, p5 and p10. On the whole similar staining patterns were observed at p2, p5 and p10, it was noted that staining for both tropomyosin and the oxytocin receptor appeared to be lighter at p10 compared to p2 however quantitative and statistical analysis was not performed due to the qualitative nature of the technique. (Figure 7) shows representative slides from (A) p2 and (B) p10.

\section{Discussion}

In this study, we have shown that primary cells isolated and cultured from paired myometrial biopsies are viable and responsive for at least ten passages. Upper and lower 


\section{Upper Segment}

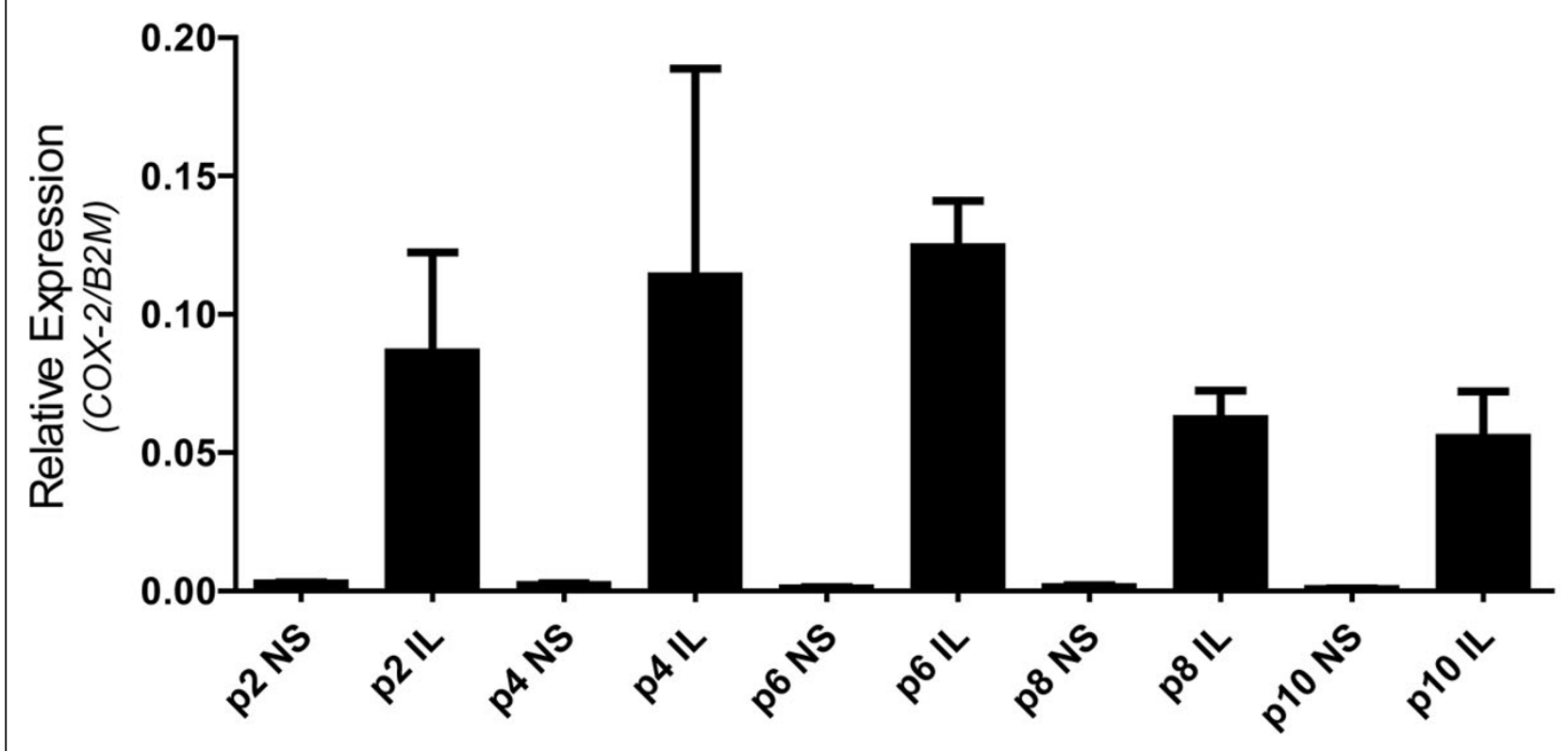

Lower Segment

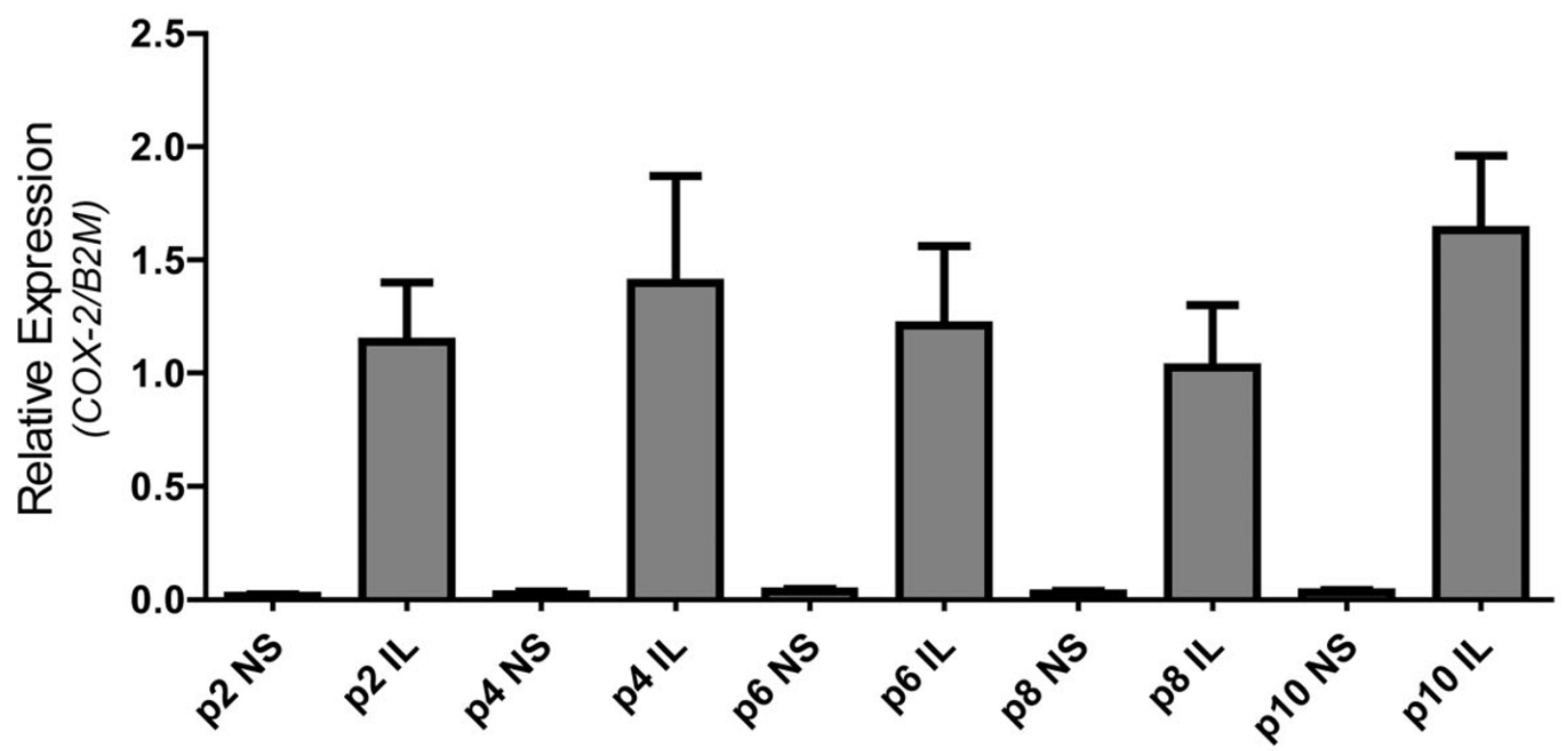

Figure 5 IL-1 $\beta$ stimulates COX-2 mRNA expression in myometrial cells from p1 through p10 Relative expression of COX-2 normalized to B2M. Data represent the mean \pm SEM of US (black) and LS (grey) myometrial cells. For simplicity only data from p2, p4, p6, p8 and p10 are depicted in the graph. NS = non-treated cells; $I L=I L-1 \beta$-stimulated cells. ANOVA ( $P=0.0007$ in upper and $P<0.0001$ in lower segment).

segment human myometrial cells continue to grow, divide and respond to an external stimulus. From p1 through to p10, upper and lower segment cells respond to IL-1 $\beta$ treatment measured by increased gene expression $(C O X-2)$ and pro-inflammatory chemokine release (CXCL8).

Human myometrial cells are elongated, spindle-shaped cells and this morphology is maintained up to p10 with 


\section{Upper Segment}

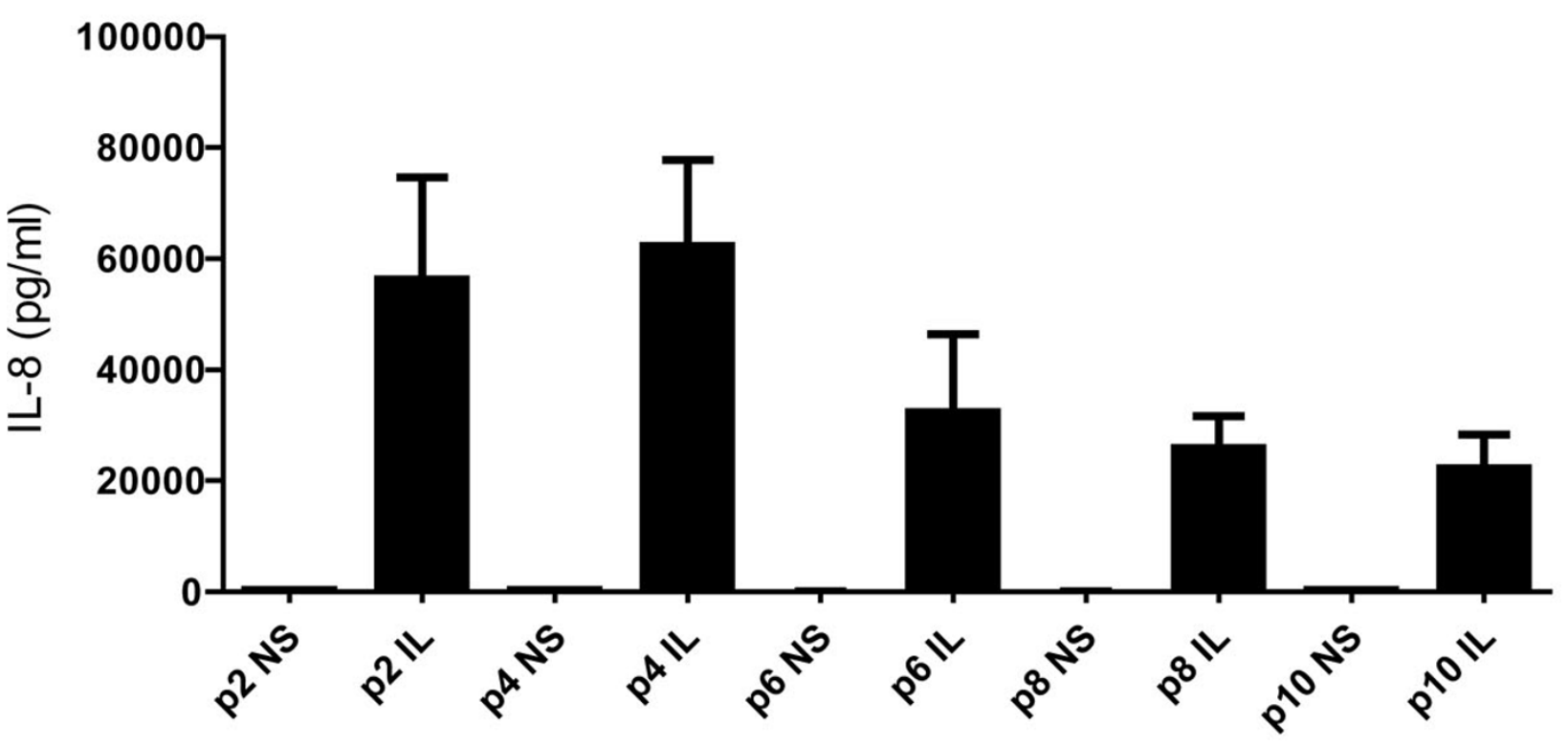

Lower segment

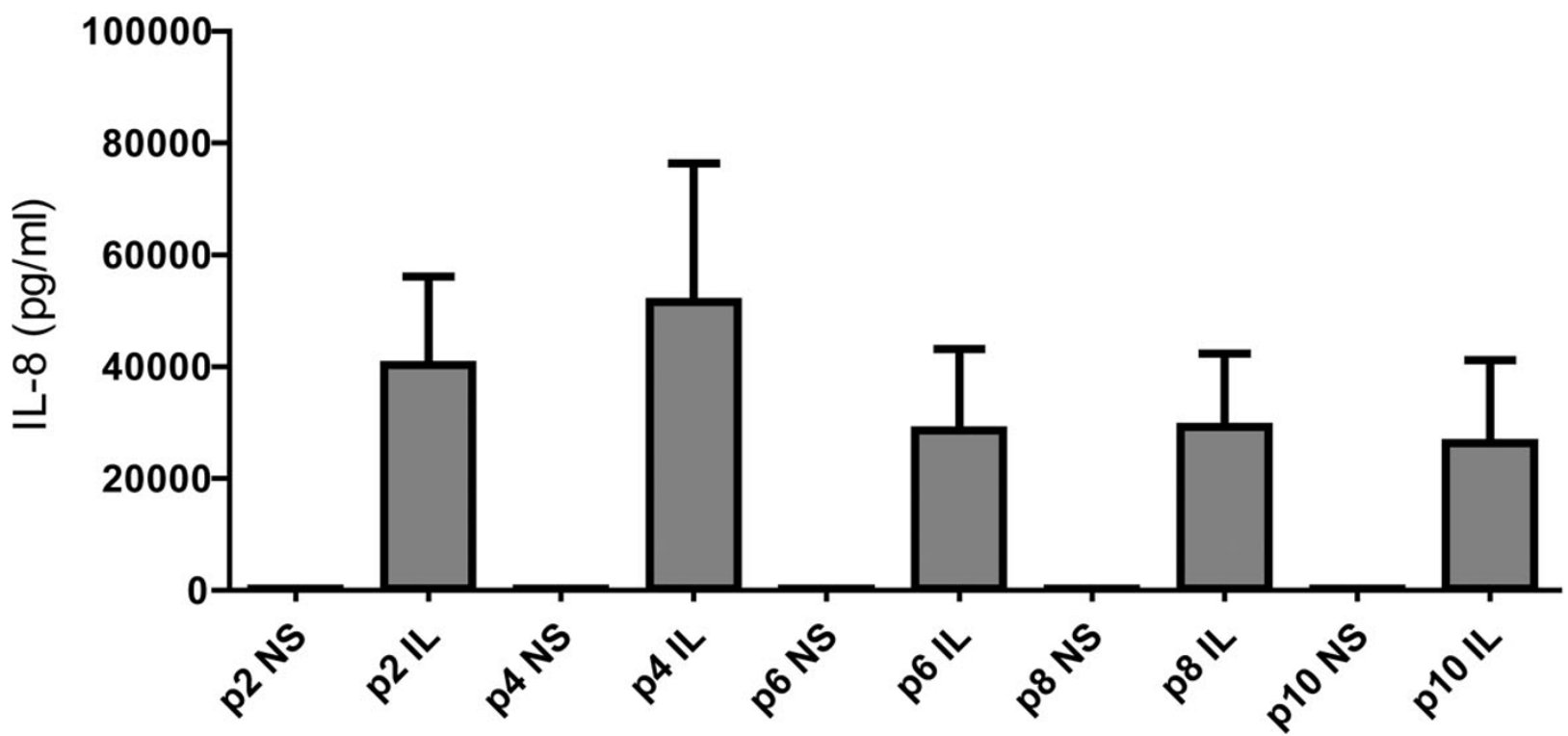

Figure 6 IL-1 $\beta$-induced CXCL8 output from p1 through p10 IL-1 $\beta$ stimulates release of CXCL8 from both upper (black) and lower (grey) segment myometrial cells Paired upper and lower segment human myometrial cells were non-treated (NS) or treated with IL-1 $\beta$ (IL). The culture supernatant was collected and CXCL8 output was quantified by ELISA. Data represent the mean \pm SEM. Only data from p2, p4, p6, p8 and p10 are depicted in the graph. ANOVA $(P<0.0001$ in upper and $P=0.0013$ in lower segment).

no discernible alterations in cell shape, size, or structure, as assessed by light microscopy. Cultured human myometrial cells expressed both smooth muscle markers ( $\alpha$ smooth muscle actin, calponin, caldesmon, tropomyosin) and fibroblast markers (vimentin, 1B10), suggesting that they may represent an intermediate myofibroblast phenotype or possibly a mixed population of myometrial smooth muscle cells and myofibroblasts. However, 


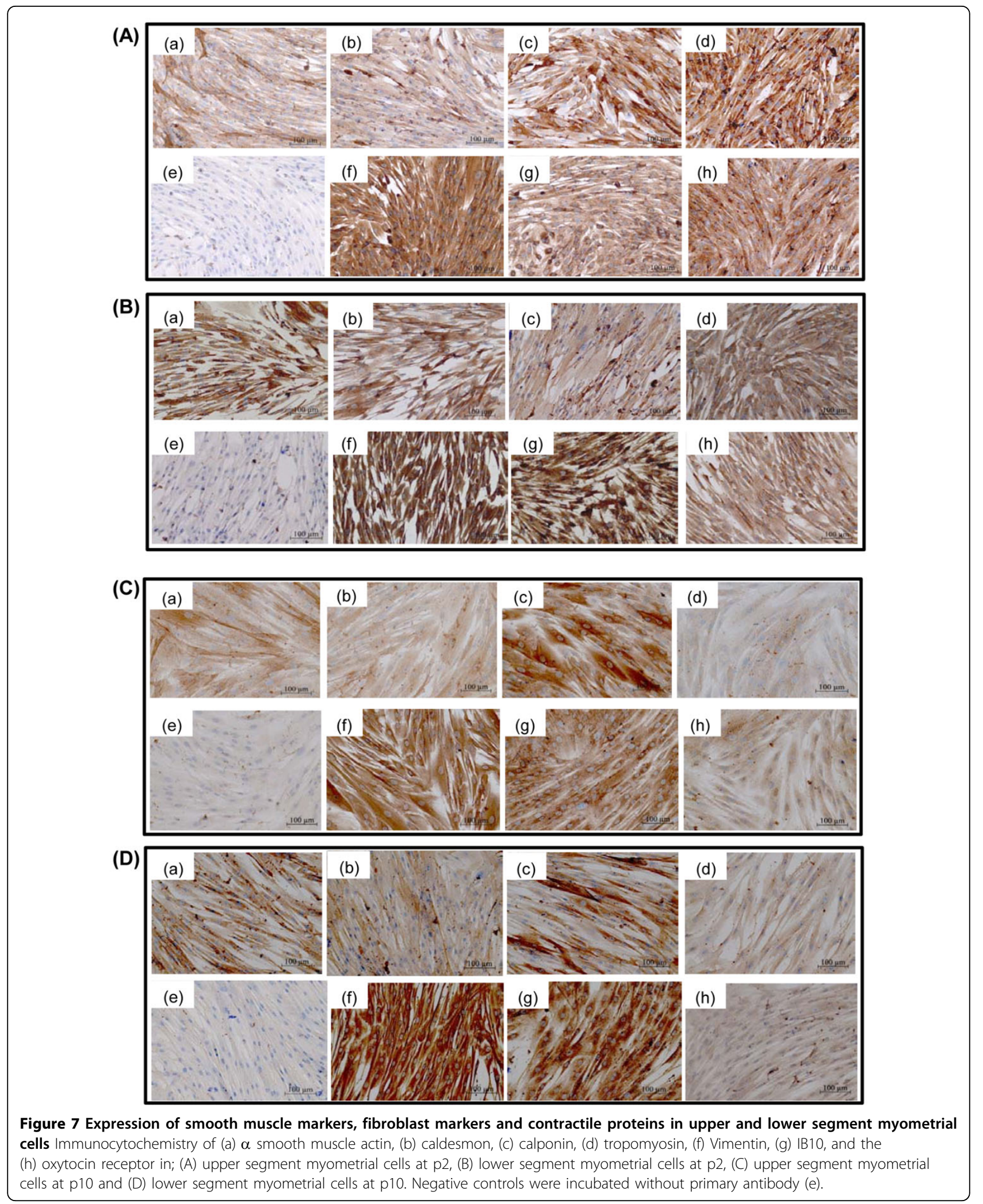


another possibility is that the presence of myofibroblast type cells is due to the nature of the cell culture technique. Future work will seek to validate this and compare expression of myofibroblast markers within myometrial tissues. Cardiac myofibroblasts stain positively for both $\alpha$ smooth muscle actin and vimentin [21] and since the cultured human myometrial cells express both proteins, this evidence could suggest that they may be myometrial myofibroblasts. Myofibroblasts are involved in wound healing, remodeling of the extracellular matrix, as well as the development of fibrosis in pathological states [22,23]. For example, exposure to allergens can increase the number of myofibroblasts in the lung [24]. Myofibroblasts may originate by differentiation of fibroblast cells or de-differentiation of smooth muscle cells [21-23]. Thus, with the extensive growth and remodeling that occurs in the uterus during pregnancy, along with the restoration to the nonpregnant size and function following delivery, it may not be surprising, that the pregnant uterus could contain myofibroblasts.

An early report establishing human myometrial cells in culture found that the cells were stable for up to one year with no morphological changes [25]. However, there is concern that the lifespan of primary cultured cells is finite and that they eventually become senescent and unresponsive. A phenomenon known as the Hayflick Limit proposes that cell populations are capable of dividing for a fixed number of times before reaching senescence [26]. To address the limited lifespan of primary cells in culture immortalized cells lines have been produced either by transfecting telomerase expression vectors into primary cells [27] or transforming cells with the human papillomavirus or the SV-40 large T antigen [28-30]. It has been suggested that cell manipulation to achieve immortalization may cause a fundamental change in the growth of the cells that is no longer truly representative of the tissue of origin [31], calling into question whether such immortalized cell lines are truly representative of the tissue of origin, while other studies have reported that introduction of telomerase does not necessarily produce 'cancer-like' behaviour or 'malignant' properties in immortalized cells [32,33].

Ten years ago, non-pregnant human myometrial cells were immortalized using telomerase and investigated for their ability to retain characteristics of the myometrium. The telomerase-immortalized cells did express smooth muscle markers ( $\alpha$ smooth muscle actin, calponin, caldesmon) but the study did not investigate the presence of fibroblast markers within the cells. The authors report that primary non-pregnant myometrial cells senesced after about 8 weeks in culture whereas the immortalized cells were still actively dividing after 10 months [9]. The concern about immortalized cells versus primary cells still persists, and many previous studies, including our own, have used primary cells only at low passages, typically $\mathrm{p} 5$ and lower [34], thus obtaining a continued supply of myometrial biopsies can be rate-limiting for the research. However, our data demonstrate that these cells can be maintained in culture for longer periods (to at least p10 as demonstrated) without loss of viability or response to IL$1 \beta$, for example. Condon et al., [9] also demonstrated that the immortalized cells maintained their ability to respond to oxytocin, which we have also shown in primary myometrial cells as oxytocin continued to stimulate calcium release by primary cells [35].

An additional area to explore would be to compare passaged cells with freshly isolated cells (p0) and/or tissue -explants which is a limitation of the current study. One of the difficulties is the ability to obtain sufficient fresh human myometrial tissue to perform the studies. However, based on the current data work is ongoing within our laboratory to develop additional models of myometrial tissue explants.

Comparison of our paired upper and lower segment myometrial cells (each pair being isolated from biopsies of the same uterus but distinct regions) revealed a number of clear differences. For example, $C O X-2$ mRNA expression was significantly greater in lower segment myometrial cells compared to upper segment cells (Figure 4), which is consistent with previously reported data from myometrial tissues [5-7]. Regional differences in gene expression have also been reported for the oxytocin receptor [3,7], connexin 43 [5,7], and the prostaglandin $E_{2}$ receptors [4,2]. In addition, we show connexin 43 and vimentin mRNA expression is significantly higher in lower segment cells compared to the upper segment myometrial cells (Figure 2B). In contrast, calponin mRNA expression was not significantly different between upper or lower cells. Taken together, these observations support the concept of a functional regionalization of the upper and lower segment of the human uterus. Of importance to note is that the significant difference in COX-2 expression between upper and lower segment cells (Figure 4A) that is also maintained from $\mathrm{p} 1$ through p10 (Figure 5). Both the upper and the lower segment cells maintain the ability to respond to IL- $1 \beta$ treatment in terms of increased COX-2 expression. However, expression of COX-2 is already significantly higher in lower segment cells compared to the upper segment cells, this is in keeping with the expression pattern observed in myometrial tissues [5]. The ability to specifically isolate and culture both upper and lower segment human myometrial cells will aid investigation of the hypothesis of functional regionalization of the pregnant uterus and provide valuable knowledge about the mechanism underlying the process of human labour.

In summary, the results of this study advocate the use of primary cultured human myometrial cells to study the expression and regulation of pregnancy- and 
labour-associated genes within the human uterus. Human myometrial cells appear to retain molecular memory of their origin and maintain their ability to respond to the inflammatory stimulus IL- $1 \beta$ for at least ten passages. Moreover, these cells are not subject to additional manipulations in order to immortalize a cell phenotype. Future work will include further molecular and functional characterization of the myometrial cell subtypes within the human uterus.

\section{Conclusions}

Primary human myometrial cells isolated from two distinct regions of the pregnant uterus offer a useful model for the study of regional functional differences and mechanistic pathways involved in the onset of human labour.

\section{List of abbreviations}

B2M: beta 2 microglobulin; CNN1: calponin; COX-2: cyclo-oxygenase-2; CXCL8: interleukin 8; GAPDH: glyceraldehyde 3-phosphate dehydrogenase;

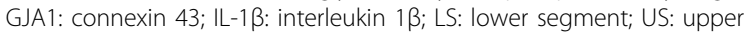
segment; VIM: vimentin.

\section{Authors' contributions}

AAM, KJR, SJL, BFM, DMO, SLW and DMS conceived the study. SLW and DMS obtained ethical approval of the study. SLW obtained written and informed consent for all patients and performed all biopsy collections. DMS, AAM, and KJR isolated, cultured and treated cells. AAM, SSB and KJR performed the molecular, biochemical and immunocytochemical assays. AAM, KJR and DMS performed the data analysis. AAM and DMS drafted the manuscript. All authors read and approved the final manuscript.

\section{Competing interests}

The authors declare that they have no competing interests.

\section{Acknowledgements}

This work was supported by Alberta Innovates-Health Solutions (Al-HS) Preterm Birth and Health Outcomes Team (\#200700595) and the Canadian Institutes of Health Research (\#MOP-82765). DMS was supported by an Al-HS scholar award and AAM by an Al-HS studentship.

\section{Declarations}

This article has been published as part of BMC Pregnancy and Childbirth Volume 13 Supplement 1, 2013: Preterm Birth: Interdisciplinary Research from the Preterm Birth and Healthy Outcomes Team (PreHOT). The full contents of the supplement are available online athttp://www. biomedcentral.com/bmcpregnancychildbirth/supplements/13/S1. All of the publication fees will be funded by the Preterm Birth and Healthy Outcomes Team Interdisciplinary Team Grant (\#200700595) from Alberta Innovates - Health Solutions, formerly the Alberta Heritage Foundation for Medical Research.

\section{Author details}

'Department of Physiology \& Pharmacology, University of Calgary, Calgary, Alberta, Canada. ${ }^{2}$ Samuel Lunenfeld Research Institute, Mount Sinai Hospital, University of Toronto, Toronto, Canada. ${ }^{3}$ Departments of Physiology, Obstetrics \& Gynecology, and Pediatrics, University of Alberta, Edmonton, Canada. ${ }^{4}$ Department of Obstetrics \& Gynaecology, University of Calgary, Alberta, Canada.

Published: 31 January 2013

\section{References}

1. Lye SJ, Ou CW, Teoh TG, Erb G, Stevens Y, Casper R, Patel FA, Challis JRG: The molecular basis of labour and tocolysis. Fetal Matern Med Rev 1998, 10:121-136.
2. Astle S, Thornton S, Slater DM: Identification and localization of prostaglandin E2 receptors in upper and lower segment human myometrium during pregnancy. Mol Hum Reprod 2005, 11:279-287.

3. Blanks AM, Vatish M, Allen MJ, Ladds G, de Wit NCJ, Slater DM, Thornton S: Paracrine oxytocin and estradiol demonstrate a spatial increase in human intrauterine tissues with labor. J Clin Endocrinol Metab 2003, 88:3392-3400.

4. Smith GCS, Wu WX, Nathanielsz PW: Effects of gestational age and labor on expression of prostanoid receptor genes in baboon uterus. Biol Reprod 2001, 64:1131-1137.

5. Sparey C, Robson SC, Bailey J, Lyall F, Europe-Finner GN: The differential expression of myometrial connexin-43, cyclooxygenase- 1 and -2 , and Gsa proteins in the upper and lower segments of the human uterus during pregnancy and labor. J Clin Endocrinol Metab 1999, 84:1705-1710.

6. Sooranna SR, Grigsby PL, Engineer N, Liang Z, Sun K, Myatt L, Johnson MR: Myometrial prostaglandin E2 synthetic enzyme mRNA expression: spatial and temporal variations with pregnancy and labour. Mol Hum Reprod 2006, 12:625-631.

7. Tattersall M, Engineer N, Khanjani S, Sooranna SR, Roberts VH, Grigsby PL, Liang Z, Myatt L, Johnson MR: Pro-labour myometrial gene expression: are preterm labour and term labour the same? Reproduction 2008, 135:569-579.

8. Word RA, Stull JT, Casey ML, Kamm KE: Contractile elements and myosin light chain phosphorylation in myometrial tissue from nonpregnant and pregnant women. J Clin Invest 1993, 92:29-37.

9. Condon J, Yin S, Mayhew B, Word RA, Wright WE, Shay JW, Rainey WE: Telomerase immortalization of human myometrial cells. Biol Reprod 2002 67:506-514.

10. Riley M, Baker PN, Tribe RM, Taggart MJ: Expression of scaffolding, signalling and contractile-filament proteins in human myometria: effects of pregnancy and labour. J Cell Mol Med 2005, 9:122-134.

11. Malmstrom $E$, Sennstrom M, Holmberg A, Frielingsdorf $H$, Eklund $E$, Malmstrom L, Tufvesson E, Gomez MF, Westergren-Thorsson G, EkmanOrdeberg G, Malmstrom A: The importance of fibroblasts in remodelling of the human uterine cervix during pregnancy and parturition. Mol Hum Reprod 2007, 13:333-341.

12. Rohr S: Cardiac fibroblasts in cell culture systems: myofibroblasts all along? J Cardiovasc Pharmacol 2011, 57:389-399.

13. Chow L, Lye SJ: Expression of the gap junction protein connexin- 43 is increased in the human myometrium toward term and with the onset of labor. Am J Obstet Gynecol 1994, 170:788-95.

14. Döring B, Shynlova O, Tsui P, Eckardt D, Janssen-Bienhold U, Hofmann F, Feil S, Feil R, Lye SJ, Willecke K: Ablation of connexin43 in uterine smooth muscle cells of the mouse causes delayed parturition. J Cell Sci 2006, 119:1715-22.

15. Belt AR, Baldassare JJ, Molnár M, Romero R, Hertelendy F: The nuclear transcription factor NF-kappaB mediates interleukin-1 beta-induced expression of cyclooxygenase-2 in human myometrial cells. Am J Obstet Gynecol 1999, 181:359-66.

16. Elliott CL, Slater DM, Dennes W, Poston L, Bennett PR: Interleukin 8 expression in human myometrium: changes in relation to labor onset and with gestational age. Am J Reprod Immunol 2000, 43:272-7.

17. Romero R, Brody DT, Oyarzun E, Mazor M, Wu YK, Hobbins JC, Durum SK: Infection and labor. III. Interleukin-1: a signal for the onset of parturition. Am J Obstet Gynecol 1989, 160:1117-23.

18. Phaneuf S, Europe-Finner GN, Varney M, MacKenzie IZ, Watson SP, LopezBernal A: Oxytocin-stimulated phosphoinositide hydrolysis in human myometrial cells: involvement of pertussis toxin-sensitive and -insensitive G-proteins. J Endocrinol 1993, 136:497-509.

19. Tribe RM, Moriarty P, Poston L: Calcium homeostatic pathways change with gestation in human myometrium. Biol. Reprod 2000, 63:748-755.

20. Livak KJ, Schmittgen TD: Analysis of relative gene expression data using real-time quantitative $P C R$ and the $2-\Delta \Delta C_{T}$ method. Methods 2001, 25:402-408.

21. Eyden B: The myofibroblast: phenotypic characterization as a prerequisite to understanding its functions in translational medicine. J Cell Mol Med 2008, 12:22-37.

22. Hinz B, Phan SH, Thannickal VJ, Galli A, Bochaton-Piallat ML, Gabbiani G: The myofibroblast: one function, multiple origins. Am J Pathol 2007, 170:1807-1816.

23. Hinz B: The myofibroblast: paradigm for a mechanically active cell. J Biomech 2010, 43:146-155. 
24. Kelly MM, O'Connor TM, Leigh R, Otis J, Gwozd C, Gauvreau GM, Gauldie J, O'Byrne PM: Effects of budesonide and formoterol on allergen-induced airway responses, inflammation, and airway remodeling in asthma. J Allergy Clin Immunol 2010, 125:349-356.

25. Casey ML, MacDonald PC, Mitchell MD, Snyder JM: Maintenance and characterization of human myometrial smooth muscle cells in monolayer culture. In vitro 1984, 20:396-403.

26. Hayflick L, Moorhead PS: The serial cultivation of human diploid cell strains. Exp Cell Res 1961, 25:585-621.

27. Bodnar AG, Ouellette M, Frolkis M, Holt SE, Chiu CP, Morin GB, Harley CB, Shay JW, Lichtsteiner S, Wright WE: Extension of life-span by introduction of telomerase into normal human cells. Science 1998, 279:349-352.

28. Perez-Reyes N, Halbert CL, Smith PP, Benditt EP, McDougall JK: Immortalization of primary human smooth muscle cells. Proc Natl Acad Sci 1992, 89:1224-1228.

29. Qian J, Hendrix EM, Larsen WJ, Dorn GW, Lessard JL: Establishment and characterization of a conditionally immortalized smooth muscle/ myometrial-like cell line. Mol Reprod Dev 1997, 47:284-294

30. Chapdelaine P, Kang J, Boucher-Kovalik S, Caron N, Tremblay JP, Fortier MA: Decidualization and maintenance of a functional prostaglandin system in human endometrial cell lines following transformation with SV40 large T antigen. Mol Hum Reprod 2006, 12:309-319.

31. Farwell DG, Shera KA, Koop Jl, Bonnet GA, Matthews CP, Reuther GW, Coltrera MD, McDougall JK, Klingelhutz AJ: Genetic and epigenetic changes in human epithelial cells immortalized by telomerase. Am J Pathol 2000, 156:1537-1547.

32. Morales CP, Holt SE, Ouellette M, Kaur K, Yan Y, Wilson KS, White MA Wright WE, Shay JW: Absence of cancer-associated changes in human fibroblasts immortalized with telomerase. Nat Genet 1999, 21:115-118.

33. Dickson MA, Hahn WC, Ino Y, Ronfard V, Wu JY, Weinberg RA, Louis DN Li FP, Rheinwald JG: Human keratinocytes that express hTERT and also bypass a $16^{\mathrm{INK} 4 \mathrm{a}}$-enforced mechanism that limits life span become immortal yet retain normal growth and differentiation characteristics. Mol Cell Biol 2000, 20:1436-1447.

34. Sooranna SR, Engineer N, Liang Z, Bennett PR, Johnson MR: Stretch and interleukin 1 beta: pro-labour factors with similar mitogen-activated protein kinase effects but differential patterns of transcription factor activation and gene expression. J Cell Physiol 2007, 212:195-206.

35. Mitchell BF, Aguilar HN, Mosher A, Wood S, Slater DM: The uterine myocyte as a target for prevention of preterm birth. FW in ObGYN 2012.

doi:10.1186/1471-2393-13-S1-S7

Cite this article as: Mosher et al:: Development and validation of primary human myometrial cell culture models to study pregnancy and labour. BMC Pregnancy and Childbirth 2013 13(Suppl 1):S7.

\section{Submit your next manuscript to BioMed Central and take full advantage of:}

- Convenient online submission

- Thorough peer review

- No space constraints or color figure charges

- Immediate publication on acceptance

- Inclusion in PubMed, CAS, Scopus and Google Scholar

- Research which is freely available for redistribution

Submit your manuscript at www.biomedcentral.com/submit
Biomed Central 